\title{
A Correlative Study of Reading Speed and Reading Comprehension of the Second Year Students of SMP Islam Sultan Fattah Salatiga in the Academic Year of 2007/2008
}

\author{
Inna Naili Izzatul Laila \\ English Department of Educational Faculty \\ State Institute for Islamic Studies \\ (STAIN)Salatiga \\ innanaili@gmail.com
}

\begin{abstract}
This study is conducted to find out the profile of students' speed reading skill and the students' reading comprehension, as well as to prove if there is significant correlation between the students' skill in reading speed and reading comprehension of students of SMP Islam Sultan Fattah Salatiga in the academic year of 2007/2008. The writer applies random sampling technique to take the sample (40) from the total of population of 81 students. Furthermore, the profile of students' reading speed skill in the text comprehension is observed through applying reading speed limited by time. From such a test, the writer knows how many words produced by students every minute. The students' reading comprehension, in addition, can be seen from the result of the answered of questions. The data is analyzed using correlative statistics. From the result, the writer finds that there is no correlation between reading speed and reading comprehension of the students. It is shown from the result $r_{0}=0,027$ and $r_{t}=0,312$ in the level of significance 5\%. Then, there are many factors that influence reading speed and the comprehension as children weakness of vocabularies and the lack of concentration in reading.
\end{abstract}

Keywords: Reading Speed, Reading Comprehension

\begin{abstract}
Abstrak
Studi ini dilakukan untuk mendeskripsikan kemampuan siswa dalam membaca cepat dan pemahaman dalam membaca, serta mencari hubungan yang signifikan antara kemampuan siswa dalam membaca cepat dan memahami bacaan siswa SMP Islam Sultan Fattah Salatiga tahun akademik 2007/2008. Penulis menggunakan teknik random sampling untuk menentukan sampel (40) dari total populasi 81 siswa. Lebih jauh lagi, kemampuan siswa dalam membaca cepat diukur melalui tes membaca cepat yang dibatasi oleh waktu. Dari tes tersebut, peneliti dapat mengetahui berapa banyak kata yang diproduksi oleh siswa setiap menit. Di samping itu,
\end{abstract}

REGISTER, VOL. 1, N0. 1, 2008 
pemahaman siswa terhadap bacaan dapat dilihat dari hasil dari pertanyaanpertanyaan yang dijawab oleh siswa. Data dianalisis menggunakan formula statistik korelatif. Dari hasil tersebut, peneliti menemukan bahwa tidak ada hubungan yang significant antara kecepatan siswa dalam membaca dengan pemahaman terhadap bacaan. Hal itu terlihat dari hasil $r_{0}=0,027$ dan $r_{t}=0,312$ di level signifikansi 5\%. Selain itu, ada banyak factor yang mempengaruhi kecepatan membaca dan pemahaman seperti kurangnya kosakata dan konsentrasi saat membaca.

Kata Kunci: Kecepatan Membaca, Pemahaman dalam Membaca

\section{Introduction}

Reading is one of the language skills that should be emphasized in teaching and learning English. It is an ability to comprehend, not simply recognize letters, forms, and symbols. Without comprehending, reading maybe useless. According to Carrein and Eisterhold (1991), comprehending the text is an interactive process between the reader's background knowledge and the text itself.

Furthermore, there are many factors influencing students' ability of reading comprehension; one of them is reading speed. Skill in speed reading is interesting to those who continually read a great deal of material in a short time, for sure with comprehension. A skillful speed reader is able to understand the meaning of sentence at glance, the average reader usually reads 200 to 250 words per minute. However, a skillful speed reader may read over 6000 words per minute.

To improve the students' ability to comprehend the reading text accompanied by speed reading, therefore, teachers have to help the students increase their ability in efficient reading habits. To support such an aim, the writer is encouraged to conduct a research dealing with reading speed and reading comprehension as well as it significance correlation of both items. This study aims to answer the following research questions.

REGISTER, VOL. 1, N0. 1, 2008 
1. How far is the students' speed reading in the second years of SMP Islam Sultan Fattah in the academic year 2007/2008?

2. How far is the students' reading comprehension skill of the second years of SMP Islam Sultan Fattah in the academic year 2007/2008?

3. Is there any significant correlation between the students' reading speed and reading comprehension of the second years of SMP Islam Sultan Fattah in the academic year 2007/2008?

\section{Definition of Reading}

Many definitions and explanations of reading have been formulated, some complementary to another, others contradictory. According to Edithia (1988), reading is the meaningful interpretation of printed or written verbal symbol. It means that reading is a result of the interaction between perception of graphic symbols that represent language and the reader's language skill, cognitive skill, and the knowledge of the world. Rivers (1981) states that reading is the most important activity in a language class, not only as a source of information and pleasurable activity, but also as a means of consolidating and extending one's knowledge of the language. Meanwhile, Martha Dallman (1977) defines reading as a verbal process interrelated to thinking and with all other communication abilities such as listening, speaking, and writing. Specifically, reading is the process of reconstructing from the printed patterns

on the page of the ideas and information intended by author. Furthermore, Mahmoud (1992) conveys that reading is the ability to comprehend, not simply to recognize letters, forms, and symbols.

\section{The Purpose of Reading}

REGISTER, VOL. 1, N0. 1, 2008 
Dealing with the purpose of reading, Mahmoud (1992) points out that reading has many goals. Some of them are:

1. Reading for specific information is a common form of reading used to discover specific or limited information.

2. Reading for application is used to accomplish a special task.

3. Reading for pleasure and entertainment includes reading popular magazines, newspaper, novels, and other similar materials.

4. Reading for ides; this type of reading requires paying special attention to main ideas and concepts and the nature of the presented information. The reader's skills through major topics, headings, illustrations and conclusions in order to obtain a general idea of the content. Reading for specific ides is enhanced, through familiarity with the overall knowledge of the subject.

5. Reading for understanding; it requires comprehension of the relationship between the information introduced and overall knowledge of the subject. Then, it requires understanding in the relationship of topics to sentences, paragraphs, and the main ideas. The reader must observe the association between facts, data, and other details.

\section{The Method of Reading}

Mahmoud (1992) elaborates the six methods to fulfilling the purpose of reading. They are:

1. Previewing

2. Skimming and scanning

3. Reading for study

REGISTER, VOL. 1, N0. 1, 2008 


\section{Critical reading}

5. Reading for critical evaluation, which can be undertaken in two stages, namely introductory and intensive stage.

6. Speed reading

\section{Speed Reading}

Speed reading is a collection of reading methods which attempt to increase rates of reading without greatly reducing comprehension or retention. It is characterized by analyzing trade-offs between measurement of speed and comprehension, recognizing that different types of reading call for different speed and comprehension rates, and that those rates may be improved with practice.

\section{Kinds of Speed Reading}

In applying this method, an efficient reader varies his speed based on the material requirement (Raygor et.all, 1981) that is distinguished into four major rates of reading i.e.:

1. Skimming rate

It is used to find reference, to locate new material, to answer a specific question, or to get the general idea of a selection passage.

2. Very rapid reading rate

It is important to review familiar material, to get reading a light novel or fast-moving short story for its plot.

3. Rapid rate

REGISTER, VOL. 1, N0. 1, 2008 
It is used in fiction, characterization, mood, sensory imagery, or anticipation of outcome, or in nonfictional text. It is also employed to find the main idea, make generalization, or sequence.

4. Average rate

It is applied in the more complex fiction for characterization and plot analysis, nonfiction of mode rate difficulty to notice the detail, to grasp the relationship between main ideas, or to distinguish between fact and opinion.

5. Slow rate

It is used to master content, including detail, to read highly factual material, to evaluate quality and literary merit, or to solve a problem of the directions.

\section{Reading Comprehension}

Edithia (1988) states that reading comprehension most likely occurs when students are reading what they want to read. Or at least when they see some reasons to do so. Comprehension itself is a construction process because if involves all of the elements of the reading process, working together. It is the rason of purpose for reading.

\section{Research Methodology}

it is a quantitative research that consists of two variables i.e. the reading speed as independent variable $(\mathrm{X})$ and the reading comprehension as dependent variable $(\mathrm{Y})$. The writer uses test and documentation as data collection method and correlative study as technique of data analysis that is formulated as follows.

REGISTER, VOL. 1, N0. 1, 2008 


$$
r_{x y}=\frac{\sum X Y-\frac{\left(\sum X\right)\left(\sum Y\right)}{N}}{\sqrt{\left\{\sum X^{2}-\frac{\left(\sum X\right)^{2}}{N}\right\}\left\{\sum Y^{2}-\frac{\left(\sum Y\right)^{2}}{N}\right\}}}
$$

In which,

$r \quad:$ Correlation coefficient of variable $X$ and $Y$

$\sum X Y:$ The sum of the product multiplying the reading speed test score and reading comprehension test scores

$\sum X \quad$ : The sum of the reading speed test scores

$\sum Y:$ The sum of the reading comprehension test scores

$\sum X^{2} \quad$ : The sum of square reading speed test scores

$N \quad$ : Total number of respondent

The subject of the research is the second year students of SMP Islam Sultan Fattah Salatiga in the Academic Year of 2007/2008 that consists of 81 students. To determine the sample, the writer use random sampling technique. Derived from such a technique of sample, the writer examines 40 students for the sake of the study.

\section{Discussion}

To find the students' reading speed, the writer uses reading sppd tes that is limited by time. From this test, the writer observes how many words produced by students every minute. The students' reading comprehension, moreover, can be seen from the result of the answered questions that follow the text. There ten items and four choices for each questions. For each correct answer, then, the writer will give ten points. Table 1 represents the result of the reading speed.

Table 1

REGISTER, VOL. 1, N0. 1, 2008 
The Result of Reading Speed $(X)$

\begin{tabular}{|c|c|c|}
\hline No & Name & The Score \\
\hline 1 & Nofi Fatmawati Putri & 84 \\
\hline 2 & Siti Zumrotun & 101 \\
\hline 3 & Rizka Rahmawati & 119 \\
\hline 4 & Winda Listyaningtyas & 140 \\
\hline 5 & Mutik Atul Khusniyah & 94 \\
\hline 6 & Henny Octoviana & 92 \\
\hline 7 & Ika & 105 \\
\hline 8 & Lia Octavia & 98 \\
\hline 9 & Nafiatun & 146 \\
\hline 10 & Siti Nurjanah & 119 \\
\hline 11 & Anna Setyani & 138 \\
\hline 12 & Istianah & 144 \\
\hline 13 & Eko Sadono & 103 \\
\hline 14 & Agus Aslimin & 93 \\
\hline 15 & Aulia Rizqillah & 124 \\
\hline 16 & Arifin & 95 \\
\hline 17 & Heru Hermawan & 90 \\
\hline 18 & Iskandar & 106 \\
\hline 19 & Ariyanto & 163 \\
\hline 20 & Tofan & 144 \\
\hline 21 & Ahmad Luqman & 87 \\
\hline 22 & Arifatul Khuzaimah & 94 \\
\hline 23 & Teguh Prasetyo & 71 \\
\hline 24 & Fitri Fatonah & 98 \\
\hline 25 & Afandi & 90 \\
\hline 26 & Setyowati & 152 \\
\hline 27 & Ihya'udin & 81 \\
\hline 28 & Rubiyanto & 91 \\
\hline 29 & Melda Dwi Vaulalina & 123 \\
\hline 30 & Suwandi & 101 \\
\hline 31 & Uswatun Khasanah & 93 \\
\hline 32 & Vivin & 93 \\
\hline 33 & Poniah & 124 \\
\hline 34 & Intan Puspita Sari & 124 \\
\hline
\end{tabular}

REGISTER, VOL. 1, N0. 1, 2008 


\begin{tabular}{|c|l|c|}
35 & Solekhah Puji Lestari & 86 \\
\hline 36 & Sulastri & 71 \\
\hline 37 & Nur Azizah & 129 \\
\hline 38 & Alfi Nikmah & 86 \\
\hline 39 & Siti Rusmiati & 115 \\
\hline 40 & Putri Nuryanti & 114 \\
\hline
\end{tabular}

In this step, the writer determines the measurement for result of reading speed. To determine the interval, the writer uses formula:

$i=\frac{(B a-B b)+1}{4}$

$i=\frac{(163-71)+1}{4}$

$i=23,25$

$i=23$

Note:

$i=$ interval

$B a=$ highest score

$B b=$ lowest score

The percentage distribution of reading speed of the subject of the study can be seen in the table 2 .

Table 2

The Percentage Distribution of Reading Speed

\begin{tabular}{|c|c|c|c|c|}
\hline No & Score & Sample & Percentage & Criteria \\
\hline 1 & $140-163$ & 6 & $15 \%$ & Excellent \\
\hline 2 & $117-139$ & 8 & $20 \%$ & Good \\
\hline 3 & $94-116$ & 12 & $30 \%$ & Fair \\
\hline 4 & $71-93$ & 14 & $35 \%$ & Poor \\
\hline & Total & 40 & $100 \%$ & \\
\hline
\end{tabular}

In order to obtain the result of the students' reading speed, the writer uses formula:

REGISTER, VOL. 1, N0. 1, 2008 


$$
\begin{aligned}
& P=\frac{\sum X}{N .100} \times 100 \% \\
& P=\frac{4321}{40.100} \times 100 \% \\
& P=108,025
\end{aligned}
$$

In which:

$P$ : The score obtained

$\sum X$ : The sum of score $X$

\section{$N$ : Sample}

Meanwhile, the students' reading comprehension is shown on the following table.

\section{Table 3}

The Result of Reading Comprehension (Y)

\begin{tabular}{|c|l|c|}
\hline No & \multicolumn{1}{|c|}{ Name } & The Score \\
\hline 1 & Nofi Fatmawati Putri & 50 \\
\hline 2 & Siti Zumrotun & 40 \\
\hline 3 & Rizka Rahmawati & 30 \\
\hline 4 & Winda Listyaningtyas & 30 \\
\hline 5 & Mutik Atul Khusniyah & 60 \\
\hline 6 & Henny Octoviana & 50 \\
\hline 7 & Ika & 50 \\
\hline 8 & Lia Octavia & 60 \\
\hline 9 & Nafiatun & 60 \\
\hline 10 & Siti Nurjanah & 40 \\
\hline 11 & Anna Setyani & 50 \\
\hline 12 & Istianah & 60 \\
\hline 13 & Eko Sadono & 50 \\
\hline 14 & Agus Aslimin & 40 \\
\hline 15 & Aulia Rizqillah & 50 \\
\hline 16 & Arifin & 50 \\
\hline 17 & Heru Hermawan & 50 \\
\hline 18 & Iskandar & 50 \\
\hline 19 & Ariyanto & 30 \\
\hline
\end{tabular}

REGISTER, VOL. 1, N0. 1, 2008 


\begin{tabular}{|l|l|l|}
20 & Tofan & 50 \\
\hline 21 & Ahmad Luqman & 30 \\
\hline 22 & Arifatul Khuzaimah & 50 \\
\hline 23 & Teguh Prasetyo & 40 \\
\hline 24 & Fitri Fatonah & 40 \\
\hline 25 & Afandi & 40 \\
\hline 26 & Setyowati & 70 \\
\hline 27 & Ihya'udin & 30 \\
\hline 28 & Rubiyanto & 40 \\
\hline 29 & Melda Dwi Vaulalina & 50 \\
\hline 30 & Suwandi & 40 \\
\hline 31 & Uswatun Khasanah & 40 \\
\hline 32 & Vivin & 60 \\
\hline 33 & Poniah & 30 \\
\hline 34 & Intan Puspita Sari & 30 \\
\hline 35 & Solekhah Puji Lestari & 50 \\
\hline 36 & Sulastri & 50 \\
\hline 37 & Nur Azizah & 30 \\
\hline 38 & Alfi Nikmah & 50 \\
\hline 39 & Siti Rusmiati & 40 \\
\hline 40 & Putri Nuryanti & 50 \\
\hline
\end{tabular}

In this research, the writer also classifies the result of reading comprehension as described as follows.

$$
\begin{aligned}
& i=\frac{(B a-B b)+1}{4} \\
& i=\frac{(70-30)+1}{4} \\
& i=10,25 \\
& i=10
\end{aligned}
$$

Note:

$i=$ interval

$B a=$ highest score

$B b=$ lowest score

REGISTER, VOL. 1, N0. 1, 2008 
The percentage of students' reading comprehension is shown on the following table.

\section{Table 4}

The Percentage Distribution of Reading Comprehension

\begin{tabular}{|c|c|c|c|c|}
\hline No & Score & Sample & Percentage & Criteria \\
\hline 1 & $60-69$ & 6 & $15 \%$ & Excellent \\
\hline 2 & $50-59$ & 16 & $40 \%$ & Good \\
\hline 3 & $40-49$ & 10 & $25 \%$ & Fair \\
\hline 4 & $30-39$ & 8 & $20 \%$ & Poor \\
\hline & Total & 40 & $100 \%$ & \\
\hline
\end{tabular}

To measure the result of the students' reading comprehension, the writer uses the formula:

$$
\begin{aligned}
P & =\frac{\sum X}{N .100} \times 100 \% \\
P & =\frac{1810}{40.100} \times 100 \% \\
P & =45,25
\end{aligned}
$$

In which:

$P:$ The score obtained

$\sum Y$ : The sum of score $Y$

$N$ : Sample

\section{Correlation Analysis}

To measure the correlation between reading speed and reading comprehension, the writer employs the following formula.

$$
r_{x y}=\frac{\sum X Y-\frac{\left(\sum X\right)\left(\sum Y\right)}{N}}{\sqrt{\left\{\sum X^{2}-\frac{\left(\sum X\right)^{2}}{N}\right\}\left\{\sum Y^{2}-\frac{\left(\sum Y\right)^{2}}{N}\right\}}}
$$

Furthermore, the result is shown in the following table.

REGISTER, VOL. 1, N0. 1, 2008 
Table 5

The Computation of Coefficient $X$ and $Y$

\begin{tabular}{|c|c|c|c|c|c|}
\hline No & $\mathrm{X}$ & $\mathrm{Y}$ & $\mathrm{X}$ & $\mathrm{Y}$ & $\mathrm{XY}$ \\
\hline 1 & 84 & 50 & 7056 & 2500 & 4200 \\
\hline 2 & 101 & 40 & 10201 & 1600 & 4040 \\
\hline 3 & 119 & 30 & 14161 & 900 & 3570 \\
\hline 4 & 140 & 30 & 19600 & 900 & 4200 \\
\hline 5 & 94 & 60 & 8836 & 3600 & 5640 \\
\hline 6 & 92 & 50 & 8464 & 2500 & 4600 \\
\hline 7 & 105 & 50 & 11025 & 2500 & 5250 \\
\hline 8 & 98 & 60 & 9604 & 3600 & 5880 \\
\hline 9 & 146 & 60 & 21316 & 3600 & 8760 \\
\hline 10 & 119 & 40 & 14161 & 1600 & 4760 \\
\hline 11 & 138 & 50 & 19044 & 2500 & 6900 \\
\hline 12 & 144 & 60 & 20736 & 3600 & 8640 \\
\hline 13 & 103 & 50 & 10609 & 2500 & 5150 \\
\hline 14 & 93 & 40 & 8649 & 1600 & 3720 \\
\hline 15 & 124 & 50 & 15376 & 2500 & 6200 \\
\hline 16 & 95 & 50 & 9025 & 2500 & 4750 \\
\hline 17 & 90 & 50 & 8100 & 2500 & 4500 \\
\hline 18 & 106 & 50 & 11236 & 2500 & 5300 \\
\hline 19 & 163 & 30 & 26569 & 900 & 4890 \\
\hline 20 & 144 & 50 & 20736 & 2500 & 7200 \\
\hline 21 & 87 & 30 & 7569 & 900 & 2610 \\
\hline 22 & 94 & 50 & 8836 & 2500 & 4700 \\
\hline 23 & 71 & 40 & 5041 & 1600 & 2840 \\
\hline 24 & 98 & 40 & 9604 & 1600 & 3920 \\
\hline 25 & 90 & 40 & 8100 & 1600 & 3600 \\
\hline 26 & 152 & 70 & 23104 & 4900 & 10640 \\
\hline 27 & 81 & 30 & 6561 & 900 & 2430 \\
\hline 28 & 91 & 40 & 8281 & 1600 & 3640 \\
\hline 29 & 123 & 50 & 15129 & 2500 & 6150 \\
\hline 30 & 101 & 40 & 10201 & 1600 & 4040 \\
\hline 31 & 93 & 40 & 8649 & 1600 & 3720 \\
\hline 32 & 93 & 60 & 8649 & 3600 & 5580 \\
\hline 33 & 124 & 30 & 15376 & 900 & 3720 \\
\hline & & & & & \\
\hline 5 & & & & \\
\hline
\end{tabular}

REGISTER, VOL. 1, N0. 1, 2008 


\begin{tabular}{|c|c|c|c|c|c|}
34 & 124 & 30 & 15376 & 900 & 3720 \\
\hline 35 & 86 & 50 & 7396 & 2500 & 4300 \\
\hline 36 & 71 & 50 & 5041 & 2500 & 3550 \\
\hline 37 & 129 & 30 & 16641 & 900 & 3870 \\
\hline 38 & 86 & 50 & 7396 & 2500 & 4300 \\
\hline 39 & 115 & 40 & 13225 & 1600 & 4600 \\
\hline 40 & 114 & 50 & 12996 & 2500 & 5700 \\
\hline & 4321 & 1810 & 487675 & 86100 & 195780 \\
\hline
\end{tabular}

From the result above, the $r_{0}=0,0272$ and the $r_{t}=0,312$. On the 5\% signification degree, $r_{0}<r_{t}$. It means that $\mathrm{H}_{0}$ is received where there is no correlation between reading speed and reading comprehension.

Based on the result of the speed reading test, the writer finds that there are 8 students that still need a lot of time for understanding the passage. This problem happens because the students feel insecure when they came across with many unknown words, so it influenced the students' speed in reading. Meanwhile, there are 10 students classified into fair criteria since they have reasonable vocabulary.

Rate of reading is not the primary goal in reading, but abilities and needs. An excellent reader usually has ability to apply reading strategy. The have not only a good vocabulary mastery but also high concentration when they face the text. A poor reader, in other side, has the lack of inellcetual maturity to bring meaning to the printed material. He tends to decode even familiar word slowly. Some of them have the binocular or fusion difficulties. They also have inadequate comprehension ability. Most of the poor readers make too many regressions.

\section{Conclusion}

From the analysis conducted, the speed reading of the second year of students of SMP Islam Sultan Fattah Salatiga in the academic year 2007/2008 is poor.

REGISTER, VOL. 1, N0. 1, 2008 
However, their reading comprehension are good. Meanwhile, there is no correlation between reading speed and reading comprehension of the students. It happens because the students still require time to comprehend the passage.

\section{References}

Mahmoud, Shah. 1992. Research and Writing A Complete Guide an Handbook. Virginia: Butterway publications.

Raygor, Alton. Reading at Efficient Rates. University of Minnesota.

Simanjuntak, Editia. 1988. Developing Reading Skill for EFL Students. Jakarta: Depdikbud.

REGISTER, VOL. 1, N0. 1, 2008 